\title{
Chagas disease: Present status of pathogenic mechanisms and chemotherapy
}

\author{
Juan Diego Maya ${ }^{*}{ }^{*}$, Myriam Orellana1 $^{1}$, Jorge Ferreira' ${ }^{1}$, Ulrike Kemmerling ${ }^{2}$, Rodrigo López-Muñoz ${ }^{1}$ \\ and Antonio Morello ${ }^{*}$. \\ 1 Programa de Farmacología Molecular y Clínica, ICBM, Facultad de Medicina, Universidad de Chile. \\ 2 Programa de Anatomía y Biología del Desarrollo, ICBM, Facultad de Medicina, Universidad de Chile/Facultad de ciencias de la Salud, Universidad de Talca.
}

\begin{abstract}
There are approximately 7.8 million people in Latin America, including Chile, who suffer from Chagas disease and another 28 million who are at risk of contracting it. Chagas is caused by the flagellate protozoan Trypanosoma cruzi. It is a chronic disease, where $20 \%-30 \%$ of infected individuals develop severe cardiopathy, with heart failure and potentially fatal arrhythmias.

Currently, Chagas disease treatment is more effective in the acute phase, but does not always produce complete parasite eradication during indeterminate and chronic phases. At present, only nifurtimox or benznidazole have been proven to be superior to new drugs being tested. Therefore, it is necessary to find alternative approaches to treatment of chronic Chagas.

The current treatment may be rendered more effective by increasing the activity of anti-Chagasic drugs or by modifying the host's immune response. We have previously shown that glutathione synthesis inhibition increases nifurtimox and benznidazole activity. In addition, there is increasing evidence that cyclooxygenase inhibitors present an important effect on $T$. cruzi infection. Therefore, we found that aspirin reduced the intracellular infection in RAW 264.7 cells and, decreased myocarditis extension and mortality rates in mice. However, the long-term benefit of prostaglandin inhibition for Chagasic patients is still unknown.
\end{abstract}

Key terms: Chagas disease, chemotherapy, nifurtimox, Trypanosoma cruzi, prostaglandins

\section{INTRODUCTION}

Chagas disease is caused by Trypanosoma cruzi, a flagellated protozoan transmitted to humans either by transfusion of infected blood, from an infected mother to her child, or by its most important vector, a blood-sucking bug (Triatoma infestans, a.k.a. 'vinchuca'), which carries the parasite in its contaminated feces. In several patients, the infection may be unnoticed or develop acute symptoms. In the majority of cases, the acute phase resolves spontaneously. In about onethird of all cases, a chronic form develops around 10-20 years later, after an indeterminate phase, causing irreversible damage to heart, esophagus, and colon, with severe disorders of nerve conduction of these organs. Patients with severe chronic disease become progressively more ill, and ultimately die, usually from their heart condition.

Epidemiologic approach to Chagas disease: Importance of the problem and future trends

Chagas disease continues to represent a health threat for an estimated 28 million people, living mostly in Latin America. While Chagas disease occurs throughout Mexico, Central, and Southern America, the clinical manifestations, and the epidemiological characteristics are different in the diverse endemic zones. However, in $20 \%$ to $30 \%$ of infected individuals, the disease results in severe cardiopathy or megaoesophagus/megacolon.

The strategy for Chagas disease control is based on vector control; systematic screening of blood donors in all endemic countries; detection and treatment of congenital transmission; and treatment of infected children and acute cases.
Accordingly to WHO information (WHO, 2007), the number of infected persons in 21 endemic countries is estimated as $7,694,500(1.448 \%)$; this represents a reduction of $50 \%$ from infection rates in 1990 . There are approximately 150,000 people in Chile who are already infected or at risk, with 41,200 new cases each year $(7.775$ per 100,000$)$ due to vector transmission and 14,385 new cases of congenital Chagas disease. Several estimates indicate that there are still some 20,000 deaths per year due to Chagas disease in endemic regions. This is unacceptably high. In addition, it is a parasitic disease with greater a economic burden on the Americas due to its long chronicity. This is why Chagas disease represents the second highest disease burden among tropical diseases in the Americas (Coura, 2009; Coura and Dias, 2009).

The migration of people infected with T. cruzi poses a public health threat in countries where there is no vectorborne parasite, such as Canada, the US and Spain, with reported cases of transmission of T. cruzi via blood products. The risk of transmission of the parasite by a transfusion of one unit of $500 \mathrm{ml}$ of whole blood ranges between $12 \%$ and $20 \%$ (Coura and Dias, 2009). Similarly, several cases of Chagas disease associated with organ transplantation have been reported in the United States (Gonzalez-Granado et al., 2009; Schmunis and Yadon, 2009).

Other disease control challenges that persist or have recently emerged include: i) continuity and sustainability of control programs in regions where control of domestic vector populations has been achieved; ii) problems posed by the risk of re-infestation by secondary vectors in houses treated with insecticides, as well as the continued control of sylvatic or peri-domestic vectors; iii) inadequate global surveillance of infection and disease rates and reporting based on 
diagnostic tools that already exist, as well as the need for improved diagnosis and prognosis of disease progression; iv) limitations of existing drugs for treatment (For more than 20 years only two drugs have been available to treat Chagas, and both have limited efficacy, as well as frequent and significant side effects. While the efficacy of drug treatment has been validated in infected people younger than 16 years of age, it is not known if the same drugs can indeed halt disease progression in adult patients, or if their use can be recommended to those at an indeterminate phase of the disease); v) a dearth of tools in clinical studies to rapidly assess the efficacy of therapeutic treatments being identified by the research community, even if the capacity to do these studies exists (The knowledge and tools for management of the cardiac or digestive symptoms that may result from Chagas disease exists; however, we know very little about how to make these interventions available to the patients or about the social costs associated with the disease) vi) a deficiency of treatment guidelines that are congruent with regional differences in disease manifestations (WHO, 2007).

Clinical aspects of Chagas disease:

During the acute phase, there may be no symptoms or a range of signs and symptoms, such as fever, muscle aches and pains, malaise, sweating, increased size of the liver and spleen, heart failure due to myocardial inflammation (myocarditis), pericardial effusion and, less often, affects to the brain, such as meningoencephalitis. Cardiac involvement is present in more than $90 \%$ of cases. In addition, there is intense parasitism in almost all organs. The diagnosis is established in less than $10 \%$ of cases, possibly due to mild symptoms. The clinical course in most cases is toward spontaneous recovery (Marin-Neto and Rassi, 2009).

The latent or indeterminate phase lasts 10 to 30 years. It is characterized by the absence of clinical symptoms, but serology is positive and there is some degree of cardiac involvement evidenced by minimal, but persistent, inflammation (Dubner et al., 2008; Marin-Neto and Rassi, 2009; Punukollu et al., 2007; Tanowitz et al., 2009).

Symptoms and physical signs of chronic Chagas heart disease arise from heart failure, cardiac arrhythmias, and arterial or venous thromboembolism. It is common for patients with Chagas heart disease to relate atypical chest pain. Heart failure is usually biventricular, which is the most frequent and severe manifestation of Chagas disease and is associated with poor prognosis and high mortality rates compared to heart failure from other causes (Rassi and Rassi, 2009; Rassi et al., 2009b). The clinical signs and symptoms are typical of heart failure and include: i) prominent apical impulse; ii) regurgitant murmurs from mitral and tricuspid valves; iii) wide splitting of the second heart sound due to right bundle branch block; and iv) accentuated pulmonic component of second heart sound due to pulmonary hypertension (Rassi and Rassi, 2009; Rassi et al., 2009b; Rocha et al., 2009).

Cardiac arrhythmias may cause palpitations, lightheadedness, dizziness, and syncope, which may also be caused by complete heart block. There may be changes in heart rate, especially bradycardia, by alterations in the autonomous innervation. Sudden death is an occasional complication in patients with severe underlying cardiac involvement, including ventricular aneurysms, which is a characteristic finding in cardiac Chagas (Bestetti and Cardinalli-Neto, 2009; Marin-Neto and Rassi, 2009; Rassi et al., 2009a; Rassi and Rassi, 2009).

This set of signs and symptoms are nonspecific to establish the diagnosis of Chagas disease. The diagnosis is based on clinical and electrocardiographic findings and on serological tests. Electrocardiogram findings include premature ventricular beats, right bundle branch block, left anterior hemiblock, diffuse alterations of repolarization, runs of sustained ventricular tachycardia, heart block, abnormal Q waves and, in the advanced stage of the disease, atrial fibrillation and low voltage QRS (Bern et al., 2007; PanizMondolfi et al., 2009; Rassi et al., 2009a; Rassi et al., 2009c; Sousa et al., 2009; Williams-Blangero et al., 2007). In addition, echocardiography may reveal one or more areas of abnormal wall motion, but in more advanced disease, left ventricular aneurysm may be observed. The most commonly used serology tests are based on complement fixation, immunofluorescence, or ELISA assays. These tests have sensitivity and specificity rates higher than 90\%. Chagas disease can be diagnosed with greater sensitivity by the detection of T. cruzi specific sequences of DNA by PCR reaction (Britto, 2009; Sousa et al., 2009).

Pathogenesis of Chagas heart disease

Although Chagasic megaesophagus and megacolon produce typical clinical conditions in $5 \%$ to $10 \%$ of patients, Chagas cardiomyopathy is by far the most serious form of the disease.

In Chagas heart disease, through mechanisms not fully understood, the myocardial aggression remains controlled at low levels in many patients due to the complex host-parasite interrelationship. These patients remain throughout life with the so-called indeterminate form. Conversely, full-blown chronic Chagas cardiomyopathy develops in $20 \%$ to $30 \%$ of patients. This syndrome leads to complex arrhythmias, ventricular aneurysms, heart failure, thromboembolism and sudden death. Evidence from studies in animal models and in humans supports four main pathogenic mechanisms to explain Chagas heart disease: i) parasite-dependent myocardial damage; ii) immune-mediated myocardial injury; iii) cardiac dysautonomia; and iv) microvascular abnormalities and ischemia (Marin-Neto and Rassi, 2009; Rassi et al., 2009a; Rassi and Rassi, 2009; Rassi et al., 2009c; Tanowitz et al., 2009).

\section{Myocardial Damage Directly Related to Parasite Persistence}

T. cruzi antigens or its genomic material can be demonstrated in inflammatory foci from cardiac tissue during the chronic phases of the disease. This can be done through sensitive methods such as immunohistochemistry, polymerase chain reaction (PCR), and in situ hybridization (Britto, 2009; Deborggraeve et al., 2009; Duffy et al., 2009; Rassi et al., 2009a; Rassi and Rassi, 2009; Rassi et al., 2009c). Experimentally, this is demonstrated by attenuation of cardiomyopathy with parasite load reduction by trypanocidal treatment (Britto, 2009; Bustamante et al., 2008; Coura, 2009; Marin-Neto et al., 2009; Perez-Molina et al., 2009; Urbina, 2009b; Viotti et al., 2009). However, myocardial 
inflammatory infiltrates and lesions are not uniformly reduced in mice infected with different $T$. cruzi strains and treated with benznidazole (Bz) (Caldas et al., 2008; MarinNeto et al., 2009; Rassi and Rassi, 2009). In addition, there is clinical evidence of parasite persistence in host tissues due to Chagas disease reactivation in immune-compromised hosts (Duffy et al., 2009; Fiorelli et al., 2005). Thus, parasite persistence in host tissues participates directly in the pathogenic role for myocardial aggression. However, the exact mechanism whereby parasitism causes heart damage in the chronic phase is unclear. Direct myocyte aggression by the parasite and apoptosis is observed in advanced stages of heart failure (DosReis and Lopes, 2009b; Punukollu et al., 2007), but the stimulation of immune responses that are targeted at the parasite and self tissues is the most likely cause of inflammation and myocytolysis (DosReis and Lopes, 2009b).

\section{Immunologic Mechanisms for parasite control and heart damage}

Initially, the predominant immune response is proinflammatory through $\mathrm{T}$ helper (Th1) cells. During the initial phases of infection, macrophages produce cytokines such as interleukin 12 and TNF- $\alpha$ that induce production of interferon gamma (IFN- $\gamma$ ). This IFN- $\gamma$, produced by $\mathrm{CD}^{+}$ and CD8 ${ }^{+}$T-lymphocytes, is essential for the control of infection (Chessler et al., 2009; Sathler-Avelar et al., 2008; Sathler-Avelar et al., 2009; Une et al., 2003). In macrophages activated by IFN- $\gamma$, intracellular parasite growth is controlled through nitric oxide (NO) production. In addition, several other cytokines, including IL-10, IL-4 and transforming growth factor- $\beta$ (TGF- $\beta$ ) have an important role in controlling the immune response against $T$. cruzi and to prevent unwanted excessive tissue inflammation (DosReis and Lopes, 2009b; Freire-de-Lima et al., 2000; Freire-de-Lima et al., 2006) (Freire-de-Lima et al; 2000; Freire-de-Lima et al, 2006; DosReis and Lopes, 2009). In any event, IFN- $\gamma$ is essential for macrophages to kill the parasites. Moreover, IFN- modulates chemokine production and regulates the appropriate development of the inflammatory response to infection (Silva et al., 2003). This inflammatory response is necessary for parasite control, but excessive or uncontrolled heart inflammation might produce myocarditis and further, associate with severe chronic forms of the disease (SathlerAvelar et al., 2009).

Parasite persistence in host tissues is the result of successful evasive strategies used by T. cruzi. In one of them, the parasites secrete proteases responsible of TGF- $\beta$ activation (Araujo-Jorge et al., 2008; Waghabi et al., 2009; Waghabi et al., 2005). In addition, phagocytosis of apoptotic bodies originated from T-cells or neutrophils and generated by the action of TNF- $\beta$, induces a prostaglandin-dependent production of TGF- $\beta$ in macrophages. Consequently, NO production diminishes, IFN- $\gamma$ induced inflammatory response is attenuated and the parasite proliferates (Freirede-Lima et al., 2000; Freire-de-Lima et al., 2006; Gutierrez et al., 2009). Possibly, this is why there is a low parasite load associated with a relative low-grade inflammatory response in the intermediate and chronic phases of the disease. However, there is a striking discrepancy between the severity of the lesions observed during the chronic phase and the extremely low parasitemia in tissues. It is suggested that factors, such as autoimmunity, might be involved in the development of Chagasic pathology. It is clear that antiparasite and autoreactivity responses are not mutually exclusive in Chagas disease, and that a combination of these types of immune response could be involved in the establishment of pathology (Ribeiro et al., 2009b; SathlerAvelar et al., 2009; Tanowitz et al., 2009).

\section{Cardiac disautonomia}

Pathologically, disautonomia is evidenced by parasympathetic denervation and sympathetic activation. However, this is not specific to Chagas disease. In direct comparisons of autonomic innervation from heart tissue of patients that underwent cardiac transplantation, autonomic denervation was found with inflammatory and noninflammatory heart disease (fibrosis, dilated cardiomyopathy). However, absolute reduction in parasympathetic neuronal counting was more conspicuous in Chagasic patients (Machado et al., 2000). This situation can be detected before the development of ventricular dysfunction and in all phases of the disease, including the indeterminate phase and the digestive forms (Molina et al., 2006; Ribeiro et al., 2009a; Ribeiro et al., 2007; Ribeiro et al., 2001). Moreover, the autonomic system is altered due to circulating autoantibodies against myocardial adrenergic and cholinergic receptors in patients with Chagas disease (Goin et al., 1994). These autoantibodies trigger physiological, morphological, enzymatic, and molecular alterations. In addition, they could cause quantitative alterations in adrenergic and cholinergic receptors and, consequently, potential myocardial damage due to the cardiac autonomic dysfunctions known to occur in Chagasic cardiomyopathy (Hernandez et al., 2008; Ribeiro et al., 2009a; Rocha et al., 2006a; Rocha et al., 2006b). The clinical consequence of parasympathetic denervation is the absence of mechanisms, mediated by the vagus nerve, that trigger bradycardia or tachycardia in response to transient changes in blood pressure or venous return (Miziara et al., 2006; Ribeiro et al., 2009a; Rocha et al., 2009; Rocha et al., 2006b). However, the relative importance of the parasympathetic autonomic dysfunction has been recently questioned, raising the possibility that neurohormonal activation is the main underlying mechanism of disease progression (Davila et al., 2008). In this setting, neurohumoral activation presents with sinus tachycardia, low systolic blood pressure and echocardiographic evidence of severely depressed left ventricular systolic function (Davila et al., 2002). It is possible that ventricular diastolic dysfunction due to neurohormonal activation and dysautonomia are independent phenomena (Molina et al., 2006; Ribeiro et al., 2009a).

\section{Microvascular abnormalities and ischemia}

In mice infected with $T$. cruzi, microcirculatory abnormalities include focal vascular constriction, microvascular proliferation, and occlusive platelet thrombi in small epicardial and intramural coronary arteries, which lead to ischemia (Factor et al., 1985; Marin-Neto et al., 2007; MarinNeto and Rassi, 2009; Ramos and Rossi, 1999; Rossi and Ramos, 1996). The impairment of cardiac sympathetic 
function at the ventricular level that occurs early in the course of Chagas cardiomyopathy is related to regional myocardial perfusion disturbances (Hiss et al., 2009). This occurs before wall motion abnormalities can be demonstrated (Hiss et al., 2009; Simoes et al., 2000). In the same way, abnormal vasodilatation and vasoconstriction at the microcirculatory level may cause myocardial damage in patients with Chagas disease. Both conditions are associated with the progression of ventricular dysfunction (Hiss et al., 2009; Simoes et al., 2000). Transient microvascular ischemic disturbances of low intensity and short duration have been postulated to be the causative mechanisms of Chagas cardiomyopathy. This could explain the focal distribution of cell necrosis and subsequent reparative interstitial fibrosis found in Chagasic hearts, which was similar to what is seen in experimental models of ischemia and reperfusion (Ramos and Rossi, 1999). In addition, coalescent microinfarctions have been postulated to occur in watershed coronary areas, because of unopposed sympathetic overstimulation. Among other factors, this might lead to the development of aneurysms in Chagasic patients (Marin-Neto and Rassi, 2009).

Experimental studies on Chagas disease in mice have demonstrated microvascular alterations characterized by microspasms (Factor et al., 1985), microthrombi (de Oliveira et al., 2007; Samuel et al., 1983; Tanowitz et al., 1990), dysfunction of endothelial cells and increased platelet activity (Petkova et al., 2001; Tanowitz et al., 2005). There is direct interaction between platelets and inflammated endothelium when it is activated (Danese et al., 2007; Tanowitz et al., 2005) (Danese et al, 2007), for example, by $T$. cruzi infection. However, endothelial function may be preserved in patients without heart failure (ConsolimColombo et al., 2004; Tanowitz et al., 2009).

Recently, it has been suggested that members of the trans-sialidase family might play a role in endothelial cell responses to T. cruzi infection. Inactive members of the transsialidase family trigger Necrosis factor kappa beta (NF- B) activation, an expression of adhesion molecules E-selectin, VCAM-1, ICAM-1, and increase endothelial cell susceptibility to T. cruzi infection (Dias et al., 2008; Laucella et al., 1996). In addition, trypomastigotes produce neuraminidase, an enzyme that removes sialic acid from the surface of mammalian myocardial and endothelial cells. At the endothelial surface platelet aggregation and microvascular thrombosis may occur (Sousa et al., 2008; Tanowitz et al., 2009).

Other mediators involved in endothelial dysfunction in Chagas disease are endothelin and thromboxane A2 (TXA2). Endothelin mediates arteriolar spasm and inhibits cAMP, with consequent stimulation of platelet adhesion to the vascular wall. There is evidence of increased production of endothelin in Chagas disease (Tanowitz et al., 2005). Many of the sequelae associated with $T$. cruzi infection are reminiscent of the effects of TXA2, including enhanced platelet adherence and aggregation in T cruzi-infected mice, where TXA2 levels are increased (Ashton et al., 2007; Cardoni and Antunez, 2004; Tanowitz et al., 1990). In T. cruzi, prostaglandin production, including TXA2 and PGF2, is possible through a NADPH flavin oxidoreductase named "old yellow enzyme" (Kubata et al., 2002). T. cruzi derived TXA2 is important in modulating disease pathogenesis in the absence of host-derived TXA2. Ashton et al. (Ashton et al., 2007) demonstrated that TXA2 is an important factor in Chagas disease that controls parasite proliferation and the resulting inflammatory response to the infection. TXA2 is a potent proinflammatory agent that activates and facilitates cytokine production by monocytes (Caughey et al., 1997; Ganzinelli et al., 2009). TXA2 activates endothelial cells, mediating inflammatory responses, through i) increased vascular permeability; ii) increased adhesion molecule expression; and iii) leukocyte adhesion to the vessel wall (Patrono et al., 2005). TXA2 also promotes platelet activation/aggregation and degranulation as a part of its prothrombotic properties (Egan and FitzGerald, 2006). In addition, TXA2 is a potent vasoconstrictor, producing substantial narrowing of coronary arteries and resistance vessels in experimental models of myocardial infarction and unstable angina (Belhassen et al., 2003). Thromboxane A2 receptor blockers and TXA2 synthase inhibitors attenuate the effect of and the damage caused by ischemic injury and inflammation. TP expression and plasma levels of TP ligands are elevated, both locally and systemically, in several vascular and thrombotic diseases, including unstable angina, myocardial infarction, and various vasculopathies ((Belhassen et al., 2003; Patrono et al., 2005).

Long-term administration of verapamil, a calcium channel blocker with vasodilating and anti-plateletaggregating effects, attenuated myocardial lesions and increased survival in a murine model of Chagas disease (De Souza et al., 2004). Verapamil has many actions, including the modulation of inflammation, vascular flow, endothelin synthesis or release and platelet aggregation, supporting the idea that vascular compromise is an important contributing factor in the pathogenesis of cardiomyopathy (De Souza et al., 2004; Tanowitz et al., 2009).

There is also clinical evidence of the microvascular alterations in Chagas heart disease. First, 20\% to 30\% of Chagasic patients complain of chest pain resembling angina in location and character, but without relationship to effort and unrelieved by organic nitrates (Punukollu et al., 2007). Second, electrocardiograms of many patients show typical findings of ischemia, such as ST-T changes and abnormal Q waves (Bern et al., 2007; Punukollu et al., 2007; Rassi et al., 2007). However, coronary angiography in Chagas cardiomyopathy invariably demonstrates the absence of obstructive coronary disease (Marin-Neto et al., 2007; Torres et al., 1995). Third, several studies have shown myocardial perfusion abnormalities in Chagasic patients related to abnormal myocardial blood flow regulation (Hiss et al., 2009; Simoes et al., 2000). Fourth, long-term dipyridamole administration (with vasodilatator and antiplatelet activity) or short-term isosorbide dinitrate administration (a coronary vasodilatator) improved left ventricular function in Chagas heart disease patients (Kuschnir et al., 1983; Marin-Neto et al., 2007). These findings are corroborated by the report of a prothrombotic state in patients with early stages of chronic Chagas disease (Herrera et al., 2005; Herrera et al., 2003). Finally, a prospective cohort study is necessary to show the beneficial effect of long-term vasodilator or antiplatelet therapy on the clinical course of Chagasic patients with angina-like symptoms to confirm the hypothesis of chronic myocardial ischemia in Chagas cardiomyopathy. 
Role of prostaglandins in the pathogenesis of Chagas disease

Prostaglandins are synthesized from arachidonic acid by enzymes known as cyclooxygenases (COX). These exist in at least two isoforms: type 1 (COX-1), which is constitutive; and type 2 (COX-2), which is induced by inflammatory mediators, particularly cytokines (Harris et al., 2002). It has been extensively demonstrated that PGE2 is a potent immunomodulator, with both stimulatory and inhibitory effects (Celentano et al., 1995). In the acute phase of Chagas disease, there is a state of immunosuppresion and T. cruzi uses it to evade the immune response. This is mediated by $\mathrm{PGE}_{2}$ (Abdalla et al., 2008; Michelin et al., 2005).

Prostaglandins, particularly $\mathrm{PGE}_{2}$, participate in cardiac fibrosis in cases of ischemic necrosis. This is evidenced when mice treated with prostaglandin synthesis inhibitors present lower amounts of fibrosis and decreased TGF- $\beta$ levels. Thus, PGE2 contributes towards cardiac remodeling and functional deficits after infection by $T$. cruzi (Freire-de-Lima et al., 2000). Prostaglandin synthesis during T. cruzi infection is related to nitric oxide production (Durand et al., 2009; Ganzinelli et al., 2009). At least two mechanisms of oxidative stress exists, dependent or independent, with regard to the nitric oxide and cyclooxygenase pathway, where one or the other is more evident depending on the cell type or mouse strain (Freirede-Lima et al., 2006; Ganzinelli et al., 2009; Hideko Tatakihara et al., 2008; Silva et al., 2003). Phagocytosis of apoptotic bodies from T- lymphocytes or neutrophils, produced by the action of TNF- $\alpha$, generated in macrophages infected with $T$. cruzi, induces the production of TGF- $\beta$ and prostaglandin. Accordingly, the content of $\mathrm{NO}$ in the macrophage decreases, and the parasite proliferates (DosReis and Lopes, 2009a; Freire-deLima et al., 2000; Lopes and DosReis, 2000). On the other hand, high levels of PGE2 are produced by macrophages (Abdalla et al., 2008) and spleen cells from T. cruziinfected mice and the inhibition of cyclooxygenase by indomethacin resulted in marked reduction of PGE2 (Hideko Tatakihara et al., 2008; Pinge-Filho et al., 1999). During early infection, treatment with aspirin or indomethacin increased parasitemia dramatically and reduced the survival rate of T. cruzi-infected C57BL/ 6 or $\mathrm{C} 3 \mathrm{H} / \mathrm{HeN}$ mice, which are characteristically resistant to acute infection (Celentano et al, 1995). Conversely, blocking COX with aspirin, indomethacin or celecoxib tended to decrease the number of parasites in the blood and delay the mortality of Balb/c mice, in a model of acute Chagas disease (Abdalla et al., 2008; Freire-de-Lima et al., 2000). The differences could be explained by the ability of BALB/c and C57BL/6 or $\mathrm{C} 3 \mathrm{H}$ mice to produce PGE2 (Cardoni and Antunez, 2004; Kuroda et al., 2007). In addition, there are different levels of production of IL-4 in BALB/c and C57BL/6 mice strains. BALB/c mice show higher IL-3 production than in resistant C57BL/6 mice (Kuroda et al., 2007). It is also possible that inhibition of prostaglandin production in C57BL/6 mice inhibited the development of protective Th1 response. In fact, nonsteroidal anti-inflammatory drugs (NSAIDs) selectively inhibit IFN- $\gamma$ and TNF- $\alpha$ production in spleen cells (Michelin et al., 2005), natural killer (NK) and $\gamma \delta \mathrm{T}$ cells (Inaoka et al., 2006).
Treatment of Chagas disease

The drugs currently used to treat Chagas disease are nifurtimox $(\mathrm{Nx})$ and benznidazole $(\mathrm{Bz})$. Both are trypanocidal to all forms of the parasite (Maya et al., 2007; Maya et al., 1997; Urbina, 2009b). Nx and Bz act through the formation of free radicals and/or electrophilic metabolites, affecting all macromolecules of the parasite (Maya et al., 2003). However, therapy is not always successful. They can cause systemic toxicity and adverse events, posing a major threat to their clinical use and frequently compelling suspension of the therapy (Castro et al., 2006; Viotti et al., 2009). Their use is complicated by the distinct susceptibility of different parasite strains ((Filardi and Brener, 1987). Probably, this is due to diverse mechanisms including differences in the free thiol content of the parasite, deletion of copies of the 'old yellow enzyme' gene (Murta et al., 2006) or type I nitroreductase (NTR) downregulation in trypanosomes (Wilkinson et al., 2008).

At present, there are no drugs that are clinically superior to $\mathrm{Nx}$ or Bz. Numerous natural and synthetic chemical compounds with potential trypanocidal activity are being added to the list, including allopurinol and its analogues, ketoconazole and itraconazole (antifungal imidazoles), quinones, diverse nitroheterocyclic derivatives, antioxidants and other drugs in clinical use, such as phenothiazines (Apt et al., 2005; Maya et al., 2007; Urbina, 2009b). Some compounds, including sterol biosynthesis, cysteine protease and pyrophosphate metabolism inhibitors, have completed pre-clinical studies and are poised for clinical trials in Chagas disease patients (Reithinger et al., 2009; Urbina, 2009a). Yet, most of the studied compounds, for diverse reasons, such as insensibility or resistance, solubility, toxicity or low clinical efficacy, have not proven to be better than $\mathrm{Nx}$ or Bz. Besides, most antiparasitic drugs are considered orphan drugs, with the main exception of anti-malarials. Economic considerations of the pharmaceutical industry outweigh all others, because of the very low return on development costs. Consequently, it is necessary to find cheaper alternative approaches to Chagas disease treatment. This could be achieved by increasing the activity of the antiChagasic drugs presently used, or by modifying the host's immune response, which would render current therapies more effective.

In this setting, we have previously demonstrated that LButhionine (S,R)-sulfoximine (BSO) treatment of T. cruzi infected VERO cells decreased glutathione content (and consequently trypanothione content) by $50 \%$, and increased the trypanocidal activity of $\mathrm{Nx}$ and $\mathrm{Bz}$ (Faundez et al., 2008; Faundez et al., 2005). Moreover, BSO (220 mg/Kg/day) showed an anti-T. cruzi effect in mice, decreasing parasitemias and parasite burden in the heart and increasing the survival rate. Furthermore, BSO plus Nx treatment caused a significant increase in the survival rate compared to treatment with each drug alone (Faundez et al., 2008). Alternatively, we have proposed the use of aspirin to modulate innate immunity in acute T. cruzi infection and thus increase the trypanocidal action of anti-Chagasic drugs (Maya et al., 2007). In preliminary work in our laboratory, we have found that aspirin itself has an important effect on T. cruzi infection.

In cellular models of acute infection, aspirin reduced the intracellular infection in macrophage-like RAW 264.7 cells. 
Moreover, there was a clear synergy among aspirin, $\mathrm{Nx}$ and $\mathrm{Bz}$, demonstrated through isobolographyc analysis. In addition, low doses of aspirin significantly reduced parasitaemia, extension of myocarditis and mortality in Balb/c mice acutely infected with T. cruzi. Most important, in the acute phase of illness, aspirin enhances the action of $\mathrm{Nx}$, and Bz. However, the long-term benefit of prostaglandin inhibition for Chagasic patients is still unknown.

\section{Role of anti-Chagasic therapy in the chronic cardiomiopathy}

Usually, benznidazole treatment is effective for parasite eradication, mainly in the acute phase of infection, but not in the chronic stage of the disease. However, the studies of the efficacy of $\mathrm{Nx}$ and $\mathrm{Bz}$ treatment during chronic infection in mice are controversial. Garcia et al, (Garcia et al., 2005) demonstrated that $\mathrm{Bz}$ decreased cardiac lesions but were unable to completely eradicate the parasite. In the same way, Caldas et al. (Caldas et al., 2008) observed a significant decrease in parasite load in mice treated with Bz during the acute phase of infection, without effect on chronic cardiac lesions. Whereas, Bustamante et al. (Bustamante et al., 2008) showed that when $\mathrm{Bz}$ is administered for 40 days, parasitological cure and stable and protective CD8+ T central memory response are obtained. Furthermore, Bz itself can modulate the immune response during indeterminate and chronic Chagas disease (Sathler-Avelar et al., 2008; SathlerAvelar et al., 2009). In addition, persistent parasitemia with T. cruzi, along with male gender, is an independent predictor of progression of Chagas cardiomyopathy in some studies (Rassi et al., 2007). All this evidence indicates the need for Bz treatment during chronic Chagas. This is supported by clinical non-randomized studies, where the use of $\mathrm{Bz}$ was associated with reduced progression of Chagas disease and increased negative seroconversion in patients presenting non-acute disease and no heart failure (Marin-Neto et al., 2009; Viotti et al., 2006). Large-scale randomized controlled studies are in progress to provide experimental evidence supporting any recommendation about the clinical use of trypanocide therapy for improving clinical outcomes in chronic and asymptomatic T. cruzi infection (Marin-Neto and Rassi, 2009; Marin-Neto et al., 2008; Reyes and Vallejo, 2005). It is should be noted that there is not curative treatment for chronic Chagas heart disease. Heart failure in Chagas cardiomyopathy is treated in a similar manner as that produced by other causes.

In brief, Chagas disease is still a relevant public health problem in Latin America. During the acute phase, patients may present with no symptoms or have a range of signs and symptoms, including myocardial involvement. The latent or indeterminate phase lasts 10 to 30 years, where chronic Chagas heart disease manifests. Chronic Chagas heart disease might produce heart failure, cardiac arrhythmias, and arterial or venous thromboembolism that could be fatal. The four main pathogenic mechanisms to explain Chagas heart disease are i) parasite-dependent myocardial damage; ii) immune-mediated myocardial injury, induced by the parasite itself and by self-antigens; iii) alterations in the autonomic control of the heart; and iv) microvascular abnormalities and ischemia, characterized by microspasms, microthrombi, dysfunction of endothelial cells and increased platelet activity. TXA2 has a role in the disease pathogenesis by endothelial cells activation, mediating inflammatory responses, through i) increased vascular permeability; ii) increased adhesion molecule expression; and iii) leukocyte adhesion to the vessel wall. TXA2 also promotes platelet activation/aggregation and degranulation as a part of its prothrombotic properties. Prostaglandins also have a role in the pathogenics of the disease. PGE2, together with nitric oxide and TGF- $\beta$, participates in some of the mechanisms that T. cruzi mount to evade the innate immune response. As well, PGE2 contribute to cardiac remodeling and functional deficits after infection by $T$. cruzi. Current Chagas disease treatment is more effective in the acute phase. However, during indeterminate and chronic phases, the treatment does not always produces complete parasite eradication. Moreover, the drugs currently used produce diverse adverse events that could affect therapy. As well, there are varying levels of susceptibility of different parasite strains. We have previously proposed a therapeutic strategy where the trypanocidal activity of $\mathrm{Nx}$ and $\mathrm{Bz}$ is increased by other agents, such as inhibitors of glutathione synthesis (BSO) or by inhibition of prostaglandin production with aspirin.

\section{ACKNOWLEDGEMENTS}

Supported by Grant N 1090078 Fondecyt Chile and Proyecto Anillo ACT112 Programa de Investigación Asociativa CONICYT.

\section{REFERENCES}

ABDALlA, G. K., FARIA, G. E., SILVA, K. T., CASTRO, E. C., REIS, M. A., and MICHELIN, M. A. (2008): Trypanosoma cruzi: the role of PGE2 in immune response during the acute phase of experimental infection. Exp Parasitol 118, 514-21.

APT, W., ARRIBADA, A., ZULANTAY, I., SOLARI, A., SANCHEZ, G., MUNDACA, K., CORONADO, X., RODRIGUEZ, J., GIL, L. C., and OSUNA, A. (2005): Itraconazole or allopurinol in the treatment of chronic American trypanosomiasis: the results of clinical and parasitological examinations 11 years post-treatment. Ann Trop Med Parasitol 99, 733-41.

ARAUJO-JORGE, T. C., WAGHABI, M. C., SOEIRO MDE, N., KERAMIDAS, M., BAILLY, S., and FEIGE, J. J. (2008): Pivotal role for TGF-beta in infectious heart disease: The case of Trypanosoma cruzi infection and consequent Chagasic myocardiopathy. Cytokine Growth Factor Rev 19, 405-13.

ASHTON, A. W., MUKHERJEE, S., NAGAJYOTHI, F. N., HUANG, H., BRAUNSTEIN, V. L., DESRUISSEAUX, M. S., FACTOR, S. M., LOPEZ, L., BERMAN, J. W., WITTNER, M., SCHERER, P. E., CAPRA, V., COFFMAN, T. M., SERHAN, C. N., GOTLINGER, K., WU, K. K., WEISS, L. M., and TANOWITZ, H. B. (2007): Thromboxane A2 is a key regulator of pathogenesis during Trypanosoma cruzi infection. J Exp Med 204, 929-40.

BELHASSEN, L., PELLE, G., DUBOIS-RANDE, J. L., and ADNOT, S (2003): Improved endothelial function by the thromboxane A2 receptor antagonist S 18886 in patients with coronary artery disease treated with aspirin. J Am Coll Cardiol 41, 1198-204.

BERN, C., MONTGOMERY, S. P., HERWALDT, B. L., RASSI, A., JR., MARIN-NETO, J. A., DANTAS, R. O., MAGUIRE, J. H., ACQUATELLA, H., MORILLO, C., KIRCHHOFF, L. V., GILMAN, R. H., REYES, P. A., SALVATELlA, R., and MOORE, A. C. (2007): Evaluation and treatment of chagas disease in the United States: a systematic review. JAMA 298, 2171-81.

BESTETTI, R. B. and CARDINALLI-NETO, A. (2009): Prophylaxis of sudden cardiac death in chronic Chagas disease. Int J Cardiol 134, 428-9.

BRITTO, C. C. (2009): Usefulness of PCR-based assays to assess drug efficacy in Chagas disease chemotherapy: value and limitations. Mem Inst Oswaldo Cruz 104 Suppl 1, 122-35.

BUSTAMANTE, J. M., BIXBY, L. M., and TARLETON, R. L. (2008): Drug- 
induced cure drives conversion to a stable and protective CD8+ T central memory response in chronic Chagas disease. Nat Med 14, 54250.

CALDAS, I. S., TALVANI, A., CALDAS, S., CARNEIRO, C. M., DE LANA, M., DA MATTA GUEDES, P. M. and BAHIA, M. T. (2008): Benznidazole therapy during acute phase of Chagas disease reduces parasite load but does not prevent chronic cardiac lesions. Parasitol Res 103, 413-21.

CARDONI, R. L. and ANTÚNEZ, M. I. (2004): Circulating levels of cyclooxygenase metabolites in experimental Trypanosoma cruzi infections. Mediators Inflamm 13, 235-40.

CASTRO, J. A., DE MECCA, M. M. and BARTEL, L. C. (2006): Toxic side effects of drugs used to treat Chagas disease (American trypanosomiasis). Hum Exp Toxicol 25, 471-9.

CAUGHEY, G. E., POULIOT, M., CLELAND, L. G. and JAMES, M. J. (1997): Regulation of tumor necrosis factor-alpha and IL-1 beta synthesis by thromboxane A2 in nonadherent human monocytes. $J$ Immunol 158, 351-8.

CELENTANO, A. M., GORELIK, G., SOLANA, M. E., STERIN-BORDA, L., BORDA, E. and GONZALEZ CAPPA, S. M. (1995): PGE2 involvement in experimental infection with Trypanosoma cruzi subpopulations. Prostaglandins 49, 141-53.

CONSOLIM-COLOMBO, F. M., LOPES, H. F., ROSETTO, E. A., RUBIRA, M. C., BARRETO-FILHO, J. A., BARUZZI, A. C., ROCHA, N. N., MADY, C., IRIGOYEN, M. C. and KRIEGER, E. M. (2004): Endothelial function is preserved in Chagas heart disease patients without heart failure. Endothelium 11, 241-6.

COURA, J. R. (2009): Present situation and new strategies for Chagas disease chemotherapy: a proposal. Mem Inst Oswaldo Cruz 104, 549-54.

COURA, J. R. and DIAS, J. C. (2009): Epidemiology, control and surveillance of Chagas disease: 100 years after its discovery. Mem Inst Oswaldo Cruz 104 Suppl 1, 31-40.

CHESSLER, A. D., UNNIKRISHNAN, M., BEI, A. K., DAILY, J. P. and BURLEIGH, B. A. (2009): Trypanosoma cruzi triggers an early type I IFN response in vivo at the site of intradermal infection. J Immunol $182,2288-96$

DANESE, S., DEJANA, E. and FIOCCHI, C. (2007): Immune regulation by microvascular endothelial cells: directing innate and adaptive immunity, coagulation, and inflammation. J Immunol 178, 6017-22.

DAVILA, D. F., DONIS, J. H., TORRES, A., GOTTBERG, C. F., RAMONIPERAZZI, P. and ARATA DE BELLABARBA, G. (2008): Betaadrenergic blockers in chronic systolic heart failure secondary to Chagas disease. Int J Cardiol 128, 1-4.

DAVILA, D. F., ROSSELL, O. and DE BELLABARBA, G. A. (2002): Pathogenesis of chronic chagas heart disease: parasite persistence and autoimmune responses versus cardiac remodelling and neurohormonal activation. Int J Parasitol 32, 107-9.

DE OLIVEIRA, F. A., TEIXEIRA VDE, P., LINO RDE, S., JR., VINAUD, M. C. and DOS REIS, M. A. (2007): Macroscopic aspects of chronic Chagas heart disease in aging. Arq Bras Cardiol 88, 486-90.

DE SOUZA, A. P., TANOWITZ, H. B., CHANDRA, M., SHTUTIN, V., WEISS, L. M., MORRIS, S. A., FACTOR, S. M., HUANG, H., WITTNER, M., SHIRANI, J. and JELICKS, L. A. (2004): Effects of early and late verapamil administration on the development of cardiomyopathy in experimental chronic Trypanosoma cruzi (Brazil strain) infection. Parasitol Res 92, 496-501

DEBORGGRAEVE, S., CORONADO, X., SOLARI, A., ZULANTAY, I., APT, W., MERTENS, P., LAURENT, T., LECLIPTEUX, T., STESSENS, T., DUJARDIN, J. C., HERDEWIJN, P. and BUSCHER, P. (2009): T. cruzi OligoC-TesT: A Simplified and Standardized Polymerase Chain Reaction Format for Diagnosis of Chagas Disease. PLoS Negl Trop Dis 3, e450.

DIAS, W. B., FAJARDO, F. D., GRACA-SOUZA, A. V., FREIRE-DE-LIMA, L., VIEIRA, F., GIRARD, M. F., BOUTEILlE, B., PREVIATO, J. O., MENDONCA-PREVIATO, L. and TODESCHINI, A. R. (2008): Endothelial cell signalling induced by trans-sialidase from Trypanosoma cruzi. Cell Microbiol 10, 88-99.

DOSREIS, G. A. and LOPES, M. F. (2009a): The importance of apoptosis for immune regulation in Chagas disease. Mem Inst Oswaldo Cruz 104, 259-62.

DOSREIS, G. A. and LOPES, M. F. (2009b): The importance of apoptosis for immune regulation in Chagas disease. Mem Inst Oswaldo Cruz 104 Suppl 1, 259-62.

DUBNER, S., SCHAPACHNIK, E., RIERA, A. R. and VALERO, E. (2008): Chagas disease: state-of-the-art of diagnosis and management. Cardiol J 15, 493-504.
DUFFY, T., BISIO, M., ALTCHEH, J., BURGOS, J. M., DIEZ, M., LEVIN, M. J., FAVALORO, R. R., FREILIJ, H. and SCHIJMAN, A. G. (2009): Accurate real-time PCR strategy for monitoring bloodstream parasitic loads in chagas disease patients. PLoS Negl Trop Dis 3, e419.

DURAND, J. L., MUKHERJEE, S., COMMODARI, F., DE SOUZA, A. P., ZHAO, D., MACHADO, F. S., TANOWITZ, H. B. and JELICKS, L. A. (2009): Role of NO synthase in the development of Trypanosoma cruziinduced cardiomyopathy in mice. Am J Trop Med Hyg 80, 782-7.

EGAN, K. and FITZGERALD, G. A. (2006): Eicosanoids and the vascular endothelium. Handb Exp Pharmacol, 189-211.

FACTOR, S. M., CHO, S., WITTNER, M. and TANOWITZ, H. (1985): Abnormalities of the coronary microcirculation in acute murine Chagas disease. Am J Trop Med Hyg 34, 246-53.

FAÚNDEZ, M., LÓPEZ-MUNOZ, R., TORRES, G., MORELLO, A., FERREIRA, J., KEMMERLING, U., ORELLANA, M. and MAYA, J. D. (2008): Buthionine sulfoximine has anti-Trypanosoma cruzi activity in a murine model of acute Chagas disease and enhances the efficacy of nifurtimox. Antimicrob Agents Chemother 52, 1837-9.

FAÚNDEZ, M., PINO, L., LETELIER, P., ORTIZ, C., LOPEZ, R., SEGUEL, C., FERREIRA, J., PAVANI, M., MORELlO, A. and MAYA, J. D. (2005): Buthionine sulfoximine increases the toxicity of nifurtimox and benznidazole to Trypanosoma cruzi. Antimicrob Agents Chemother 49, 126-30.

FILARDI, L. S. and BRENER, Z. (1987): Susceptibility and natural resistance of Trypanosoma cruzi strains to drugs used clinically in Chagas disease. Trans $R$ Soc Trop Med Hyg 81, 755-9.

FIORELLI, A. I., STOLF, N. A., HONORATO, R., BOCCHI, E., BACAL, F., UIP, D., STRABELLI, T., ISSA, V., AMATO, V. A., FIORELLI, L. R. and OLIVEIRA, S. A. (2005): Later evolution after cardiac transplantation in Chagas disease. Transplant Proc 37, 2793-8.

FREIRE-DE-LIMA, C. G., NASCIMENTO, D. O., SOARES, M. B., BOZZA, P. T., CASTRO-FARIA-NETO, H. C., DE MELLO, F. G., DOSREIS, G. A. and LOPES, M. F. (2000): Uptake of apoptotic cells drives the growth of a pathogenic trypanosome in macrophages. Nature 403, 199-203.

FREIRE-DE-LIMA, C. G., XIAO, Y. Q., GARDAI, S. J., BRATTON, D. L., SCHIEMANN, W. P. and HENSON, P. M. (2006): Apoptotic cells, through transforming growth factor-beta, coordinately induce antiinflammatory and suppress pro-inflammatory eicosanoid and NO synthesis in murine macrophages. J Biol Chem 281, 38376-84.

GANZINELLI, S., BORDA, E., JOENSEN, L. and STERIN-BORDA, L. (2009): Chagasic antibodies induce cardiac COX-2/iNOS mRNA expression with PGE2/NO production. Int J Cardiol 134, 212-23.

GARCÍA, S., RAMOS, C. O., SENRA, J. F., VILAS-BOAS, F., RODRIGUES, M. M., CAMPOS-DE-CARVALHO, A. C., RIBEIRO-DOS-SANTOS, R. and SOARES, M. B. (2005): Treatment with benznidazole during the chronic phase of experimental Chagas disease decreases cardiac alterations. Antimicrob Agents Chemother 49, 1521-8.

GOIN, J. C., BORDA, E., LEIROS, C. P., STORINO, R. and STERINBORDA, L. (1994): Identification of antibodies with muscarinic cholinergic activity in human Chagas disease: pathological implications. J Auton Nerv Syst 47, 45-52.

GONZÁLEZ-GRANADO, L. I., ROJO-CONEJO, P., RUIZ-CONTRERAS, J. and GONZÁLEZ-TOME, M. I. (2009): Chagas disease travels to Europe. Lancet 373, 2025

GUTIÉRREZ, F. R., MINEO, T. W., PAVANELLI, W. R., GUEDES, P. M. and SILVA, J. S. (2009): The effects of nitric oxide on the immune system during Trypanosoma cruzi infection. Mem Inst Oswaldo Cruz 104, 236-45.

HARRIS, S. G., PADILLA, J., KOUMAS, L., RAY, D. and PHIPPS, R. P. (2002): Prostaglandins as modulators of immunity. Trends Immunol 23, 144-50.

HERNÁNDEZ, C. C., NASCIMENTO, J. H., CHAVES, E. A., COSTA, P. C., MASUDA, M. O., KURTENBACH, E., CAMPOS, D. E. C. A. C. and GIMENEZ, L. E. (2008): Autoantibodies enhance agonist action and binding to cardiac muscarinic receptors in chronic Chagas disease. J Recept Signal Transduct Res 28, 375-401.

HERRERA, R. N., DÍAZ, E., PÉREZ AGUILAR, R., BIANCHI, J., BERMAN, S. and LUCIARDI, H. L. (2005): [Prothrombotic state in early stages of chronic Chagas disease. Its association with thrombotic risk factors]. Arch Cardiol Mex 75 Suppl 3, S3-38-48.

HERRERA, R. N., DÍAZ, E., PÉREZ, R., CHAIN, S., SANT-YACUMO, R., RODRÍGUEZ, E., BIANCHI, J., COVIELLO, A., MIOTTI, J., FLORES, I., DE LA SERNA, F., MUNTANER, J., BERMAN, S. and LUCIARDI, H. (2003): [The prothrombotic state in early stages of chronic Chagas disease]. Rev Esp Cardiol 56, 377-82. 
HIDEKO TATAKIHARA, V. L., CECCHINI, R., BORGES, C. L. MALVEZI, A. D., GRACA-DE SOUZA, V. K., YAMADA-OGATTA, S F., RIZZO, L. V. and PINGE-FILHO, P. (2008): Effects of cyclooxygenase inhibitors on parasite burden, anemia and oxidative stress in murine Trypanosoma cruzi infection. FEMS Immunol Med Microbiol 52, 47-58.

HISS, F. C., LASCALA, T. F., MACIEL, B. C., MARÍN-NETO, J. A. and SIMOES, M. V. (2009): Changes in myocardial perfusion correlate with deterioration of left ventricular systolic function in chronic Chagas cardiomyopathy. JACC Cardiovasc Imaging 2, 164-72.

INAOKA, M., KIMISHIMA, M., TAKAHASHI, R. and SHIOHARA, T. (2006): Non-steroidal anti-inflammatory drugs selectively inhibit cytokine production by NK cells and gamma delta T cells. Exp Dermatol 15, 981-90.

KUBATA, B. K., KABUTUTU, Z., NOZAKI, T., MUNDAY, C. J., FUKUZUMI, S., OHKUBO, K., LAZARUS, M., MARUYAMA, T., MARTIN, S. K., DUSZENKO, M. and URADE, Y. (2002): A key role for old yellow enzyme in the metabolism of drugs by Trypanosoma cruzi. J Exp Med 196, 1241-51.

KURODA, E., NOGUCHI, J., DOI, T., UEMATSU, S., AKIRA, S. and YAMASHITA, U. (2007): IL-3 is an important differentiation factor for the development of prostaglandin E2-producing macrophages between C57BL/6 and BALB/c mice. Eur J Immunol 37, 2185-95.

KUSCHNIR, E., SGAMMINI, H., CASTRO, R., EVEQUOZ, C. and LEDESMA, R. (1983): [Chronic Chagas cardiomyopathy: effects of dipyradamole on ventricular dynamics]. Arq Bras Cardiol 41, 373-8.

LAUCELLA, S., DE TITTO, E. H., SEGURA, E. L., ORN, A. and ROTTENBERG, M. E. (1996): Soluble cell adhesion molecules in human Chagas disease: association with disease severity and stage of infection. Am J Trop Med Hyg 55, 629-34.

LOPES, M. F. and DOSREIS, G. A. (2000): Experimental Chagas disease: phagocytosis of apoptotic lymphocytes deactivates macrophages and fuels parasite growth. Apoptosis 5, 221-4.

MACHADO, C. R., CAMARGOS, E. R., GUERRA, L. B. and MOREIRA, M. C. (2000): Cardiac autonomic denervation in congestive heart failure: comparison of Chagas heart disease with other dilated cardiomyopathy. Hum Pathol 31, 3-10.

MARÍN-NETO, J. A., CUNHA-NETO, E., MACIEL, B. C. and SIMOES, M. V. (2007): Pathogenesis of chronic Chagas heart disease. Circulation $115,1109-23$

MARÍN-NETO, J. A. and RASSI, A., JR. (2009): Update on Chagas heart disease on the first centenary of its discovery. Rev Esp Cardiol 62, 1211-6.

MARÍN-NETO, J. A., RASSI, A., JR., AVEZUM, A., JR., MATTOS, A. C. and RASSI, A. (2009): The BENEFIT trial: testing the hypothesis that trypanocidal therapy is beneficial for patients with chronic Chagas heart disease. Mem Inst Oswaldo Cruz 104, 319-24.

MARÍN-NETO, J. A., RASSI, A., JR., MORILLO, C. A., AVEZUM, A., CONNOLLY, S. J., SOSA-ESTANI, S., ROSAS, F. and YUSUF, S. (2008): Rationale and design of a randomized placebo-controlled trial assessing the effects of etiologic treatment in Chagas' cardiomyopathy: the BENznidazole Evaluation For Interrupting Trypanosomiasis (BENEFIT). Am Heart J 156, 37-43.

MAYA, J. D., BOLLO, S., NÚNEZ-VERGARA, L. J., SQUELLA, J. A., REPETTO, Y., MORELLO, A., PERIE, J. and CHAUVIERE, G. (2003): Trypanosoma cruzi: effect and mode of action of nitroimidazole and nitrofuran derivatives. Biochem Pharmacol 65, 999-1006.

MAYA, J. D., CASSELS, B. K., ITURRIAGA-VÁSQUEZ, P., FERREIRA, J., FAUNDEZ, M., GALANTI, N., FERREIRA, A. and MORELLO, A. (2007): Mode of action of natural and synthetic drugs against Trypanosoma cruzi and their interaction with the mammalian host. Comp Biochem Physiol A Mol Integr Physiol 146, 601-20.

MAYA, J. D., REPETTO, Y., AGOSIN, M., OJEDA, J. M., TELLEZ, R. GAULE, C. and MORELLO, A. (1997): Effects of nifurtimox and benznidazole upon glutathione and trypanothione content in epimastigote, trypomastigote and amastigote forms of Trypanosoma cruzi. Mol Biochem Parasitol 86, 101-6.

MICHELIN, M. A., SILVA, J. S. and CUNHA, F. Q. (2005): Inducible cyclooxygenase released prostaglandin mediates immunosuppression in acute phase of experimental Trypanosoma cruzi infection. Exp Parasitol 111, 71-9.

MIZIARA, A. N., MOLINA, R. J., FERREIRA, B. D., BARBOSA, C. J., DIAS DA SILVA, V. J., PRATA, A. and CORREIA, D. (2006): Cardiac autonomic modulation in hypertensive patients with Chagas disease. Acta Trop 97, 188-95.

MOlinA, R. B., MATSUbARA, B. B., HUEB, J. C., ZANATI, S. G.,
MEIRA, D. A., CASSOLATO, J. L., PAIVA, S. A. and ZORNOFF, L. A. (2006): Dysautonomia and ventricular dysfunction in the indeterminate form of Chagas disease. Int J Cardiol 113, 188-93.

MURTA, S. M., KRIEGER, M. A., MONTENEGRO, L. R., CAMPOS, F. F., PROBST, C. M., AVILA, A. R., MUTO, N. H., DE OLIVEIRA, R. C., NUNES, L. R., NIRDE, P., BRUNA-ROMERO, O., GOLDENBERG, $S$. and ROMANHA, A. J. (2006): Deletion of copies of the gene encoding old yellow enzyme (TcOYE), a $\mathrm{NAD}(\mathrm{P}) \mathrm{H}$ flavin oxidoreductase, associates with in vitro-induced benznidazole resistance in Trypanosoma cruzi. Mol Biochem Parasitol 146, 151-62.

PANIZ-MONDOLFI, A. E., PEREZ-ALVAREZ, A. M., LANZA, G., MARQUEZ, E. and CONCEPCION, J. L. (2009): Amiodarone and itraconazole: a rational therapeutic approach for the treatment of chronic Chagas disease. Chemotherapy 55, 228-33.

PATRONO, C., GARCÍA RODRÍGUEZ, L. A., LANDOLFI, R. and BAIGENT, C. (2005): Low-dose aspirin for the prevention of atherothrombosis. N Engl J Med 353, 2373-83.

PEREZ-MOLINA, J. A., PEREZ-AYALA, A., MORENO, S., FERNANDEZGONZALEZ, M. C., ZAMORA, J. and LOPEZ-VELEZ, R. (2009): Use of benznidazole to treat chronic Chagas disease: a systematic review with a meta-analysis. J Antimicrob Chemother 64, 1139-1147.

PETKOVA, S. B., HUANG, H., FACTOR, S. M., PESTELL, R. G., BOUZAHZAH, B., JELICKS, L. A., WEISS, L. M., DOUGLAS, S. A., WITTNER, M. and TANOWITZ, H. B. (2001): The role of endothelin in the pathogenesis of Chagas disease. Int J Parasitol 31, 499-511.

PINGE-FILHO, P., TADOKORO, C. E. and ABRAHAMSOHN, I. A (1999): Prostaglandins mediate suppression of lymphocyte proliferation and cytokine synthesis in acute Trypanosoma cruzi infection. Cell Immunol 193, 90-8.

PUNUKOLLU, G., GOWDA, R. M., KHAN, I. A., NAVARRO, V. S. and VASAVADA, B. C. (2007): Clinical aspects of the Chagas heart disease. Int J Cardiol 115, 279-83.

RAMOS, S. G. AND ROSSI, M. A. (1999): Microcirculation and Chagas disease: hypothesis and recent results. Rev Inst Med Trop Sao Paulo 41, 123-9.

RASSI, A., JR., DIAS, J. C., MARIN-NETO, J. A. and RASSI, A. (2009a): Challenges and opportunities for primary, secondary and tertiary prevention of Chagas disease. Heart 95, 524-34.

RASSI, A., JR. and RASSI, A. (2009): Predicting prognosis in patients with Chagas disease: Why are the results of various studies so different? Int J Cardiol.

RASSI, A., JR., RASSI, A. and MARIN-NETO, J. A. (2009b): Chagas heart disease: pathophysiologic mechanisms, prognostic factors and risk stratification. Mem Inst Oswaldo Cruz 104 Suppl 1, 152-8.

RASSI, A., JR., RASSI, A. and MARIN-NETO, J. A. (2009c): Chagas heart disease: pathophysiologic mechanisms, prognostic factors and risk stratification. Mem Inst Oswaldo Cruz 104, 152-8.

RASSI, A., JR., RASSI, A. and RASSI, S. G. (2007): Predictors of mortality in chronic Chagas disease: a systematic review of observational studies. Circulation 115, 1101-8.

REITHINGER, R., TARLETON, R. L., URBINA, J. A., KITRON, U. and GURTLER, R. E. (2009): Eliminating Chagas disease: challenges and a roadmap. BMJ 338, b1283.

REYES, P. A. and VALLEJO, M. (2005): Trypanocidal drugs for late stage, symptomatic Chagas disease (Trypanosoma cruzi infection). Cochrane Database Syst Rev, CD004102.

RiBEIRO, A. L., DE CARVAlHO, A. C., LOMBARDI, F., TEIXEIRA, M. M. and ROCHA, M. O. (2009a): Enhanced parasympathetic activity in Chagas disease still stands in need of proof. Int J Cardiol 135, 406-8.

RIBEIRO, A. L., GIMENEZ, L. E., HERNANDEZ, C. C., DE CARVALHO, A. C., TEIXEIRA, M. M., GUEDES, V. C., BARROS, M. V., LOMBARDI, F. and ROCHA, M. O. (2007): Early occurrence of antimuscarinic autoantibodies and abnormal vagal modulation in Chagas disease. Int J Cardiol 117, 59-63.

RiBEIRO, A. L., MORAES, R. S., RIBEIRO, J. P., FERLIN, E. L., TORRES, R. M., OLIVEIRA, E. and ROCHA, M. O. (2001): Parasympathetic dysautonomia precedes left ventricular systolic dysfunction in Chagas disease. Am Heart J 141, 260-5.

RIBEIRO, C. H., LOPEZ, N. C., RAMIREZ, G. A., VALCK, C. E., MOLINA, M. C., AGUILAR, L., RODRIGUEZ, M., MALDONADO, I., MARTINEZ, R., GONZALEZ, C., TRONCOSO, R., LAVANDERO, S., GINGRAS, A. R., SCHWAEBLE, W. and FERREIRA, A. (2009b): Trypanosoma cruzi calreticulin: a possible role in Chagas disease autoimmunity. Mol Immunol 46, 1092-9.

ROCHA, A. L., LOMBARDI, F., DA COSTA ROCHA, M. O., BARROS, M. V., VAL BARROS VDA, C., REIS, A. M. and RIBEIRO, A. L. (2006a): 
Chronotropic incompetence and abnormal autonomic modulation in ambulatory Chagas disease patients. Ann Noninvasive Electrocardiol 11, 3-11.

ROCHA, M. O., NUNES, M. C. and RIBEIRO, A. L. (2009): Morbidity and prognostic factors in chronic chagasic cardiopathy. Mem Inst Oswaldo Cruz 104 Suppl 1, 159-66.

ROCHA, N. N., GARCIA, S., GIMENEZ, L. E., HERNANDEZ, C. C., SENRA, J. F., LIMA, R. S., CYRINO, F., BOUSKELA, E., SOARES, M. B., RIBEIRO DOS SANTOS, R. and CAMPOS DE CARVALHO, A. C. (2006b): Characterization of cardiopulmonary function and cardiac muscarinic and adrenergic receptor density adaptation in C57BL/6 mice with chronic Trypanosoma cruzi infection. Parasitology 133, 729-37.

ROSSI, M. A. AND RAMOS, S. G. (1996): Coronary microvascular abnormalities in Chagas disease. Am Heart J 132, 207-10.

SAMUEL, J., OLIVEIRA, M., CORREA DE ARAUJO, R. R., NAVARRO, M. A. and MUCCILlO, G. (1983): Cardiac thrombosis and thromboembolism in chronic Chagas heart disease. Am J Cardiol 52, 147-51.

SATHLER-AVELAR, R., VITELLI-AVELAR, D. M., MASSARA, R. L., DE LANA, M., PINTO DIAS, J. C., TEIXEIRA-CARVALHO, A., ELOISANTOS, S. M. and MARTINS-FILHO, O. A. (2008): Etiological treatment during early chronic indeterminate Chagas disease incites an activated status on innate and adaptive immunity associated with a type 1-modulated cytokine pattern. Microbes Infect 10, 103-13.

SATHLER-AVELAR, R., VITELLI-AVELAR, D. M., TEIXEIRACARVALHO, A. and MARTINS-FILHO, O. A. (2009): Innate immunity and regulatory $\mathrm{T}$-cells in human Chagas disease: what must be understood? Mem Inst Oswaldo Cruz 104, 246-51.

SCHMUNIS, G. A. and YADON, Z. E. (2009): Chagas disease: A Latin American health problem becoming a world health problem. Acta Trop.

SILVA, J. S., MACHADO, F. S. and MARTINS, G. A. (2003): The role of nitric oxide in the pathogenesis of Chagas disease. Front Biosci 8, s314-25.

SIMOES, M. V., PINTYA, A. O., BROMBERG-MARIN, G., SARABANDA, A. V., ANTLOGA, C. M., PAZIN-FILHO, A., MACIEL, B. C. and MARIN-NETO, J. A. (2000): Relation of regional sympathetic denervation and myocardial perfusion disturbance to wall motion impairment in Chagas cardiomyopathy. Am J Cardiol 86, 975-81.

SOUSA, A. S., XAVIER, S. S., FREITAS, G. R. and HASSLOCHERMORENO, A. (2008): Prevention strategies of cardioembolic ischemic stroke in Chagas disease. Arq Bras Cardiol 91, 306-10.

SOUSA, L., ROCHA, M. O., BRITTO, R. R., LOMBARDI, F. and RIBEIRO, A. L. (2009): Chagas disease alters the relationship between heart rate variability and daily physical activity. Int J Cardiol 135, 257-9.

TANOWITZ, H. B., BURNS, E. R., SINHA, A. K., KAHN, N. N., MORRIS, S. A., FACTOR, S. M., HATCHER, V. B., BILEZIKIAN, J. P., BAUM, S. G. and WITTNER, M. (1990): Enhanced platelet adherence and aggregation in Chagas disease: a potential pathogenic mechanism for cardiomyopathy. Am J Trop Med Hyg 43, 274-81.

TANOWITZ, H. B., HUANG, H., JELICKS, L. A., CHANDRA, M.,
LOREDO, M. L., WEISS, L. M., FACTOR, S. M., SHTUTIN, V., MUKHERJEE, S., KITSIS, R. N., CHRIST, G. J., WITTNER, M., SHIRANI, J., KISANUKI, Y. Y. and YANAGISAWA, M. (2005): Role of endothelin 1 in the pathogenesis of chronic chagasic heart disease. Infect Immun 73, 2496-503.

TANOWITZ, H. B., MACHADO, F. S., JELICKS, L. A., SHIRANI, J., DE CARVALHO, A. C., SPRAY, D. C., FACTOR, S. M., KIRCHHOFF, L. V. and WEISS, L. M. (2009): Perspectives on Trypanosoma cruziinduced heart disease (Chagas disease). Prog Cardiovasc Dis 51, 524 39.

TORRES, F. W., ACQUATELlA, H., CONDADO, J. A., DINSMORE, R. and PALACIOS, I. F. (1995): Coronary vascular reactivity is abnormal in patients with Chagas heart disease. Am Heart J 129, 995-1001.

UNE, C., ANDERSSON, J. and ORN, A. (2003): Role of IFN-alpha/beta and IL-12 in the activation of natural killer cells and interferongamma production during experimental infection with Trypanosoma cruzi. Clin Exp Immunol 134, 195-201.

URBINA, J. A. (2009a): Ergosterol biosynthesis and drug development for Chagas disease. Mem Inst Oswaldo Cruz 104 Suppl 1, 311-8.

URBINA, J. A. (2009b): Specific Chemotherapy of Chagas Disease: Relevance, Current Limitations and New Approaches. Acta Trop.

VIOTTI, R., VIGLIANO, C., LOCOCO, B., ALVAREZ, M. G., PETTI, M., BERTOCCHI, G. and ARMENTI, A. (2009): Side effects of benznidazole as treatment in chronic Chagas disease: fears and realities. Expert Rev Anti Infect Ther 7, 157-63.

VIOTTI, R., VIGLIANO, C., LOCOCO, B., BERTOCCHI, G., PETTI, M., ALVAREZ, M. G., POSTAN, M. and ARMENTI, A. (2006): Long-term cardiac outcomes of treating chronic Chagas disease with benznidazole versus no treatment: a nonrandomized trial. Ann Intern Med 144, 724-34.

WAGHABI, M. C., DE SOUZA, E. M., DE OliveirA, G. M., KERAMIDAS, M., FEIGE, J. J., ARAUJO-JORGE, T. C. and BAILLY, S. (2009): Pharmacological inhibition of transforming growth factor beta signaling decreases infection and prevents heart damage in acute Chagas disease. Antimicrob Agents Chemother 53, 4694-701.

WAGHABI, M. C., KERAMIDAS, M., FEIGE, J. J., ARAUJO-JORGE, T. C. and BAILLY, S. (2005): Activation of transforming growth factor beta by Trypanosoma cruzi. Cell Microbiol 7, 511-7.

WHO (2007): Reporte del grupo de trabajo científico sobre la enfermedad de Chagas : 17-20 de abril de 2005, actualizado en julio de 2007, Buenos Aires, Argentina. World Health Organization. Geneva.

WILKINSON, S. R., TAYLOR, M. C., HORN, D., KELLY, J. M. and CHEESEMAN, I. (2008): A mechanism for cross-resistance to nifurtimox and benznidazole in trypanosomes. Proc Natl Acad Sci U S A $105,5022-7$

WILLIAMS-BLANGERO, S., MAGALHAES, T., RAINWATER, E., BLANGERO, J., CORREA-OLIVEIRA, R. and VANDEBERG, J. L. (2007): Electrocardiographic characteristics in a population with high rates of seropositivity for Trypanosoma cruzi infection. Am J Trop Med Hyg 77, 495-9. 
